\title{
Conservation and sustainable use of wetlands in Nepal (CSUWN - NEP/05/G01)
}

$\mathbf{N}$ epal hosts great wetlands diversity covering a total of $7,43,756$ ha, which represents $5 \%$ of the total landmass of the country. It has nine Ramsar sites of international importance representing Himalayas, Mid Hills \& Terai. Nepal's wetlands support a wide spectrum of nationally and globally important bio-diversity and harbor 42 globally threatened species. Despite its significant biological as well as social \& cultural values, wetlands of Nepal are not getting sufficient concern and attention for its management and conservation, which has resulted into continuous loss and threats to wetlands biodiversity. The major threats to wetlands are: destruction \& degradation of wetlands habitats, loss of wetlands ecosystem integrity $\&$ depletion of species abundance \& diversity. Therefore, in order to address these gaps $\&$ issues, Government of Nepal has launched Conservation and Sustainable Use of Wetlands in Nepal (CSUWN) since 2008.

CSUWN is a joint undertaking of the Ministry of Forests and Soil Conservation (MFSC), Global Environmental Facility (GEF) and the United Nations Development Programme (UNDP). The Project is executed by MFSC. IUCN Nepal provides technical assistance to the project. CSUWN aims to build the capacity, legal and policy frameworks (both related to conservation and development) for an ecosystem management for wetlands conservation and sustainable use. Partnerships and capacity will be developed at both national and local levels to effect long term changes to the perception, value and sustainable management of wetlands in Nepal and to ensure sustainability and replication of activities even after the cessation of the project.

\section{Project goal}

The project goal is to ensure the maintenance and enhancement of wetlands biodiversity and environmental goods and services for improved local livelihoods in Nepal.

\section{Objective}

The objective of the project is to strengthen national and local capacity on ecosystem management and sustainable use of wetlands biodiversity in Nepal.

\section{Expected outcomes}

The project aims at producing three major outcomes: 1) the integration of wetlands biodiversity conservation values into national policy and planning frameworks,

2) strengthened national, institutional, technical, economic capacity and awareness for wetlands biodiversity conservation and sustainable use,

3) enhanced collaborative management of wetlands resources for conservation and sustainable livelihoods

\section{Strategy and approach}

The project attempts to address the root causes of wetlands degradation and loss by:

1. Strengthening national policy, capacity and awareness on wetlands

2. Linking national actions at two demonstration sites

3. Employing existing inter-sectoral and multistakeholder structures and mechanisms wherever possible.

4. Planning activities to influence wetlands policy and practice

The project will support to develop mechanism and procedures for mainstreaming wetlands issues in policy and planning at both national and local levels. A National Wetlands Committee (NWC) is being envisioned to address the cross sectoral needs of wetlands conservation and sustainable use. The project will also employ existing inter-sectoral \& multi-stakeholder committees and networks where possible to promote integrated development.

The project has also explicitly built in activities to test the relevance of its approaches and tools in other wetlands particularly in mid hills and high mountains. Best practices and lessons learnt will be captured and up-scaled for the benefit of local communities as well as for global environmental benefits.

The project will foster a strong learning-by-doing and adaptive management culture to be relevant and to capture the ground realities. The project will support community based user groups with targeted 
interventions to strengthen livelihood activities. Equal attention will be paid to conservation \& development issues by involving women, poor, indigenous/ marginalized \& wetlands dependent communities (WDCs). Promotion of traditional knowledge and practices will be an important aspect of its strategy. As far as possible, the project will use and strengthen existing structures \& mechanism to forge synergistic and collaborative management for sustainable wetlands conservation.

Following approaches will be adopted while implementing the programs:

\&) Using existing structures \& mechanism

@ Focus on wetlands conservation

@ Forging partnership with DDCs, VDCs, BZ institutions, CFUGs, CBOs, other institutions, UNDP supported projects [MEDEP, DRRP] \& civil societies

\& Wetland dependent communities

@ Fostering a strong learning and doing culture

\& Adaptive management

\& Sharing of experiences

\section{Management Arrangement}

The project is being implemented under the National Execution Guidelines (NEX). MFSC is the executing agency. The Project Management Unit (PMU) under the leadership of National Project Director (NPD) is responsible for the overall management of the project. The Joint Secretary of the MFSC is the designated NPD. The NPD is supported by a team of professional staff including National Project Manager (NPM), Wetland Biodiversity Specialist, Indigenous Communities \& Gender Specialist and Admin \& Finance Associate. Similarly, for field operation, a field management team comprising of Field Manager, Social Mobilizers and Administration and Finance Assistant will be responsible to implement field activities.

At the central level, the Project Outcome Board (POB) chaired by the Secretary, MFSC with representatives from various organizations (see organization chart) is responsible for policy and strategic guidance as well as for inter-sectoral coordination. The NPD acts as the Member Secretary of the POB. In order to make necessary executive decision required for the implementation of the activities, a Project Executive Board (PEB) is formed under the chairpersonship of NPD, with representatives from DNPWC, DoF, UNDP and IUCN. The NPM serves as the Member Secretary.

\section{Project Management Arrangement}

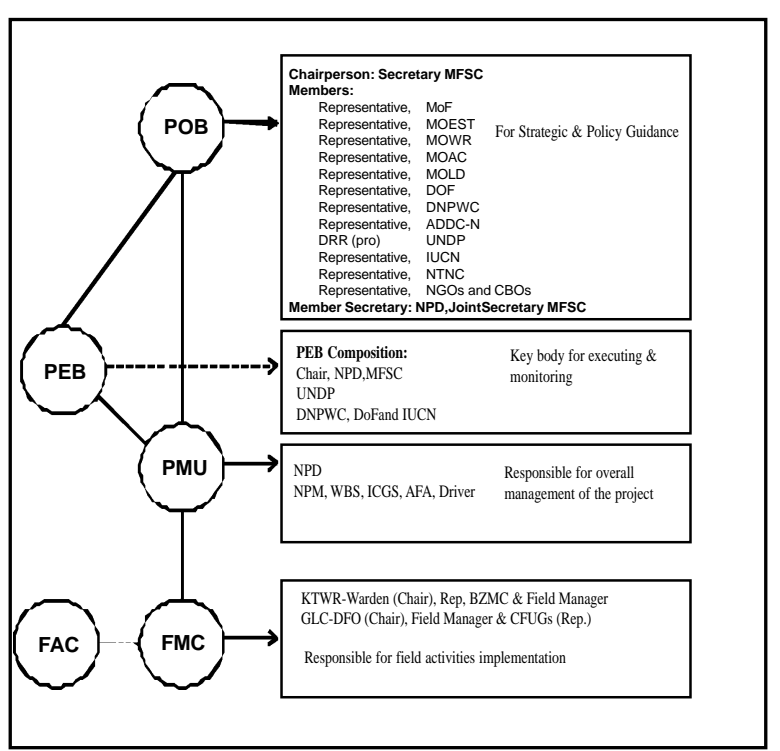

At the field level, a Field Advisory Committee (FAC) provides policy guidance and coordinates among all relevant stakeholders. The FAC is chaired by the Chairperson of District Forest Coordination Committee (DFCC) in Ghodaghodi Tal and by the Chairperson of Buffer Zone Management Committee (BZMC) in Koshi Tappu. Other members come from the District Forest Office (DFO), District Development Committee (DDC), Village Development Committee (VDC), Regional Directorate of Forests, Field Manager and other projects working in the area. The DFO and Warden act as the Member Secretary respectively in the Ghodaghodi Tal and Koshi Tappu areas.

A Field Management Committee (FMC) will be responsible for the implementation of activities at the demonstration sites as per the guidance of PMU. The FMC will be chaired by the DFO and the Warden respectively in Ghodaghodi Tal and Koshi Tappu. Members include the Field Manager and a representative from CFUGs in Ghodaghodi Tal and the BZMC in Koshi Tappu.

\section{Partners}

The project is working with different partners at different level. The main central level partners are Department of Forests (DoF) \& Department of National Parks and Wildlife Conservation (DNPWC). 
Similarly, project will work in collaboration with site level partners viz. Koshi Tappu Wildlife Reserve (KTWR), District Forests Office and its lower units, District Development Committees, Village Development Committees, Line agencies, I/N/GOs, Buffer Zone Institutions, Community Forest Institutions, Local Community, Civil Societies \& other conservation partners e.g. Western Terai Landscape Complex Project (WTLCP), Terai Arc Landscape (TAL), Bird Conservation Nepal (BCN) etc.

\section{Demonstration sites}

Two Ramsar sites representing two different ecological systems and geographical locations: Koshi Tappu Wildlife Reserve and its Buffer Zone in the Eastern part of Nepal and the Ghodaghodi lake complex in the Western part have been chosen as project demonstration sites.

\section{Ghodaghodi lake complex}

Ghodaghodi is the largest natural lowland lake of Nepal. The complex covers an area of 2563 hectares including 13 associated lakes \& ponds. It has globally significant biodiversity value as it supports 11 globally threatened faunal species, $1 \%$ of Asian Cotton Pygmy-goose, endangered species of Orchid, threatened species of Lotus and rare wild rice. Ghodaghodi Lake Complex (GLC) also forms an important wildlife corridor between the Terai and Siwalik hills. GLC area is spread over 3 VDCs of Kailali district and covers around a total population of 44,000 from over 6,000 households with majority of them from Tharu communities. The main threats for GLC include encroachment, siltation, succession and reduced inflow of water and its diversion for different purpose.

\section{Koshi Tappu Wildlife Reserve (KTWR)}

Koshi Tappu Wildlife Reserve (KTWR) is the first Ramsar site of Nepal. It is a freshwater wetland site along the flood plain of Koshi river, characterized by grassy marshes, oxbow lakes, swamp lakes and depressions which retain water throughout the year. It covers an area of $348 \mathrm{Km}^{2}$ including Buffer Zone. It is the largest heronry in Nepal and provides habitat for 467 species of birds, 114 species of waterfowls and thousands of migratory birds. The Reserve is the only remaining habitat of Asian wild water buffalo in Nepal. Gangetic dolphin, elongated tortoise and many other aquatic species are also found in the area. KTWR covers 16 VDCs of three Districts (Sunsari, Saptari \& Udaypur) with beneficiaries of about 106,000 from over 18,000 households. About 31\% of the populations comprise Wetlands Dependent Communities such as Mallah, Dusad, Kewat, Bantar, Satar and Jhangar. The major challenges and threats for KTWR include high number of feral cattle, ever changing river course, overharvesting of resources \& poaching.

\section{For further information \& correspondence please write to:$$
\text { Conservation and Sustainable Use of }
$$$$
\text { Wetlands in Nepal (CSUWN) }
$$ \\ Training Section Building, Second floor, Forestry \\ Complex, Babar Mahal, Kathmandu \\ Phone: 977-01-4226230/4229669 \\ Fax: 977-01-4229670 \\ Email: info@ wetlands.org.np \\ URL: www.wetlands.org.np}

